Rice University's Baker Institute

LATIN AMERICA INITIATIVE

RICE UNIVERSITY'S 20 YEARS

BAKER INSTITUTE 201993-2013

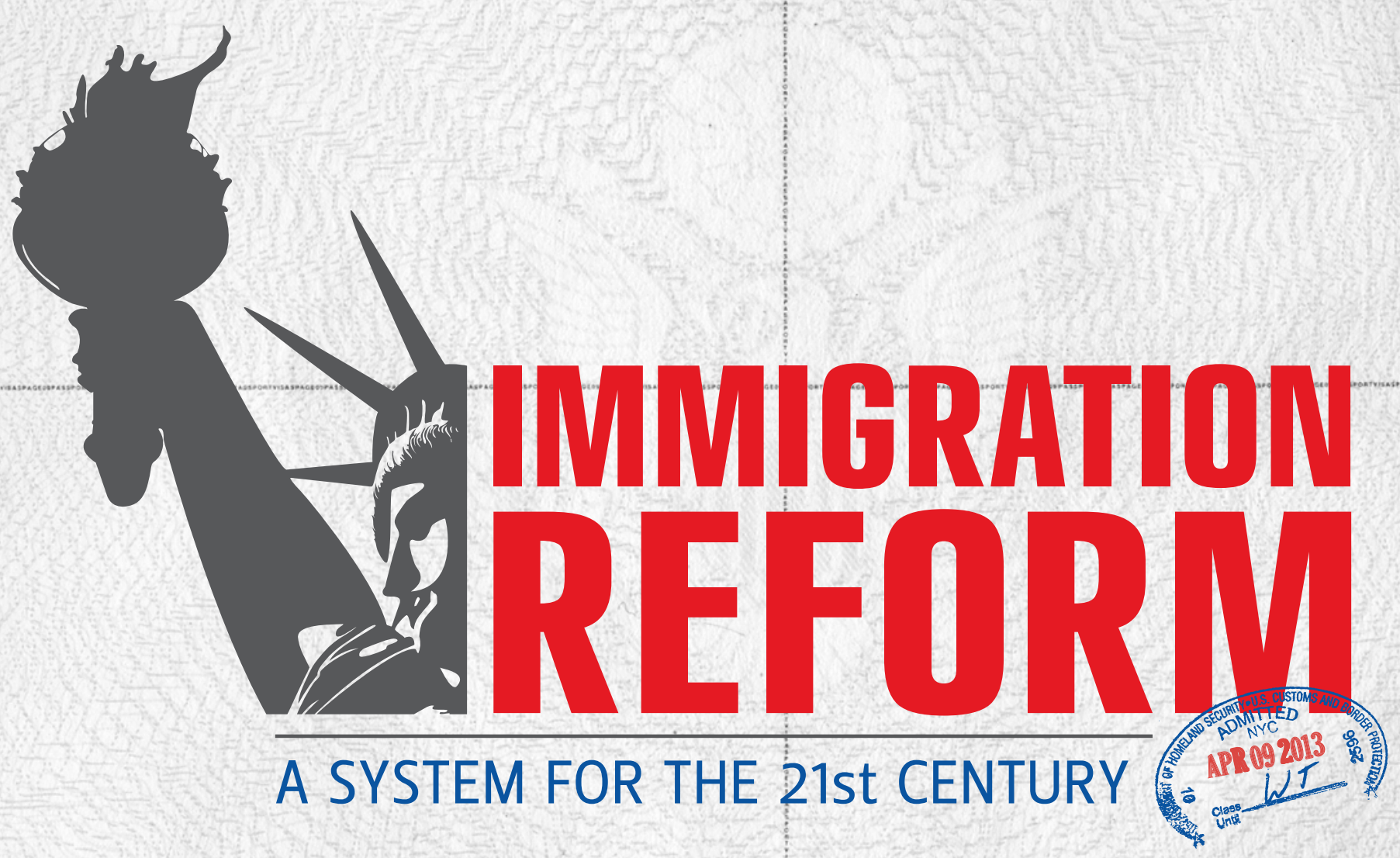

Immigration Policy and Partisan Politics in the State Legislatures: 2010-2012

Mark P. Jones, Ph.D. Benjamin Chou 


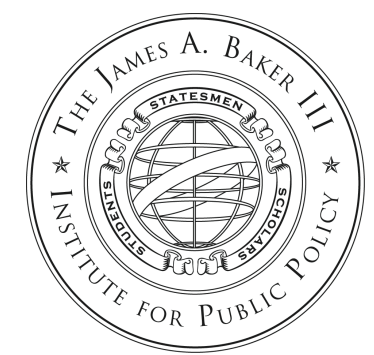

James A. Baker III Institute for Public Policy

RICE UNIVERSITY

Latin America Initiative Immigration Research Project

WORKING PAPER

\title{
IMMIGRATION POLICY AND PARTISAN POLITICS \\ IN THE STATE LEGISLATURES: 2010-2012
}

BY

\author{
Mark P. JONES, Ph.D. \\ Fellow in Political SCience, Baker Institute, AND \\ Joseph D. Jamail Chair in Latin American Studies \\ RICE UNIVERSITY \\ AND \\ BENJAMIN ChOU \\ ReseARCH AsSistant, BAKER I NSTITUTE \\ RICE UNIVERSITY
}

APRIL 2013 


\section{Immigration Policy and Partisan Politics in the State Legislatures}

THEse papers were written by a researcher (Or Researchers) Who PARTICIPATED IN A BAKER INSTITUTE RESEARCH PROJECT. WHEREVER FEASIBLE, THESE PAPERS ARE REVIEWED by OUTSIDE EXPERTS beFORE THEY ARE RELEASED. HOWEVER, THE RESEARCH AND VIEWS EXPRESSED IN THESE PAPERS ARE THOSE OF THE INDIVIDUAL RESEARCHER(S), AND DO NOT NECESSARILY REPRESENT THE VIEWS OF THE JAMES A. BAKER III INSTITUTE FOR PUBLIC POLICY.

(O) 2013 By the JAmes A. BAKER III InStitute for Public Policy of RiCe UNIVERSITY

THIS MATERIAL MAY BE QUOTED OR REPRODUCED WITHOUT PRIOR PERMISSION, PROVIDED APPROPRIATE CREDITIS GIVEN TO THE AUTHOR AND

THE JAMES A. BAKER I I I INSTITUTE For PUbliC POlicy. 


\title{
Immigration Policy and Partisan Politics in the State Legislatures
}

\begin{abstract}
One point upon which virtually everyone can agree is that the current U.S. immigration system is broken. Partially in response to federal inaction in the area of immigration reform, between 2010 and 2012 legislatures in a number of states took it upon themselves to debate and, in some instances approve, restrictive omnibus legislation designed to address the presence of undocumented immigrants within their respective borders. This study utilizes roll-call vote data from these legislatures to examine the partisan, ethnic/racial and regional dynamics surrounding the debate over this restrictive omnibus immigration legislation in these states. We highlight the extremely partisan nature of the votes on this legislation, with virtually all Republicans supporting the omnibus bills and an overwhelming majority of Democrats opposing. While there is little intra-party variance in Republican support, among Democrats rural Anglo legislators were significantly more likely than their colleagues to break with the party majority and side with the GOP legislators in support of restrictive immigration reform legislation.
\end{abstract}

\section{Immigration Policy and Partisan Politics in the State Legislatures: 2010-2012}

In 2010, the Arizona state legislature debated and ultimately passed a restrictive omnibus state-level immigration reform, widely referred to by the bill's Arizona Senate number, SB-1070. This legislation originated with the growing frustration within the Republican Party with the country's broken immigration system, in particular the large number of undocumented immigrants residing in the country, and with the stalemate on the issue that existed in Washington, D.C. The introduction and passage of SB-1070 helped produce a wave of similar legislation in a host of other states throughout the country, as primarily Republican legislative leaders and legislators utilized the legislation to burnish their conservative credentials on the hot-button issue of immigration while simultaneously sending a message to President Barack Obama and congressional Democrats (as well as to congressional Republicans) that they considered the current immigration status quo to be unacceptable. 


\section{Immigration Policy and Partisan Politics in the State Legislatures}

The public debate surrounding, and media coverage of, SB-1070 and its offspring in other states highlighted the Republican Party's increasing shift to the right on immigration policy. This shift, led for instance to the 2012 GOP presidential nominee (Mitt Romney) embracing, at least during the primary stage of the election process, the "attrition through enforcement" logic that undergirds SB-1070. ${ }^{1}$ While Romney's advocacy of "self-deportation" during a Republican presidential debate may very well have helped him in his effort to obtain the party's presidential nomination, it certainly did him no favors with Hispanic voters, who cast ballots for his Democratic opponent at a higher rate than in recent presidential elections. ${ }^{2}$

The poor performance of Republican Party in the November 2012 elections resulted in a collective realization that if the party continued to lose support among Hispanics, its days as a relevant national political party capable of winning the presidency were numbered. This in turn resulted in renewed efforts by Republicans in Congress to pass comprehensive immigration reform. And, while the prospects for reform now brighter than at any time since 2007, there still exists the possibility that the reform could be derailed by either Republican intransigence or Democratic hubris.

In this paper we examine the dynamics surrounding the debate over restrictive omnibus immigration reform legislation in the state legislatures between 2010 and 2012. We pay particular attention to the partisan dynamics surrounding the legislation, underscoring the extent to which the debate over restrictive immigration reform at the state level was first

\footnotetext{
${ }^{1}$ Highlighting the shift to the right in the GOP was the near-unanimous criticism received by conservative stalwart Rick Perry during a September 22, 2011 Republican presidential debate for his signing of legislation a decade earlier which allowed undocumented immigrants to pay in-state tuition at Texas colleges and universities. The 2001 legislation had been supported by all but two Republicans in the Texas House and three in the Texas Senate. A total of 64 Republican representatives and 12 Republican senators voted for the legislation, including representative Leo Berman who ten years later in 2011 would be one of the most prolific authors of restrictive immigration legislation filed in the state. Jones, Mark P. "The GOP Flipped, but Perry Hasn't," Texas Tribune, September 27, 2011. http://www.texastribune.org/2011/09/27/guest-column-gop-flipped-perry-wont/

${ }^{2}$ According to the Latino Decisions Election Eve Poll, Mitt Romney won only $23 \%$ of the Hispanic vote, compared to $75 \%$ for President Barack Obama. http://www.latinodecisions.com/2012-election-eve-polls/. National Exit Poll data conclude that Romney won $27 \%$ of the Hispanic vote nationally, $4 \%$ less than John McCain in 2008, and 13\% than George W. Bush in 2004. The 4\% gap is only magnified by the fact that Romney won a greater share of the popular vote than McCain (47.1\% to 45.6\%). http://www.pewhispanic.org/2012/11/07/latino-voters-in-the-2012-election/.
} 


\section{Immigration Policy and Partisan Politics in the State Legislatures}

and foremost a partisan issue, with Republicans promoting the legislation and Democrats on average opposing it. This stark partisan divide at the state-level went a great way towards creating a nation-wide image, especially in the eyes of many Hispanic voters, of a Republican Party that was anti-immigrant and therein more anti-Hispanic, and a Democratic Party that was pro-immigrant, and therein more pro-Hispanic.

Here, we first provide details on the restrictive omnibus immigration reform legislation in eleven states on which either a legislative chamber or committee held a roll call vote. We then utilize the roll call vote data to analyze inter-party and intra-party differences in support for the legislation.

\section{The Omnibus Immigration Legislation}

The latter half of the first decade of the 21st century saw a noteworthy increase in efforts by state-level and national activists within the Republican Party to adopt restrictive immigration policy at the state-level. ${ }^{3}$ In many states the moderate approach to immigration policy favored by the Republican establishment, especially that linked to the business community, was overwhelmed during this time period by conservative statelevel party activists working in concert with like-minded national organizations. The result was a substantial movement to the right within the GOP in the policy area of immigration. At the same time, an issue upon which there exist divergent opinions and positions within the Republican and Democratic parties (with for instance many moderate Republicans opposing restrictive immigration policies and many conservative Democrats supporting them) became increasingly polarized, with Republicans united in favor of restrictive omnibus immigration legislation and Democrats united, albeit to a slightly lesser degree, against it.

\footnotetext{
${ }^{3}$ Krane, Dale, 2007. "The Middle Tier of American Federalism: State Government Policy Activism During the Bush Administration," Publius: The Journal of Federalism 37: 453-57. Reich, Gary, and Jay Barth, 2012. "Immigration Restriction in the States: Contesting the Boundaries of Federalism," Publius: The Journal of Federalism 42: 422-48.
} 


\section{Immigration Policy and Partisan Politics in the State Legislatures}

This section examines the details and components of each particular restrictive immigration omnibus bill as introduced and debated in the respective chambers of state governments. The term "omnibus" follows the definition provided by the National Conference of State Legislatures (NCSL) which requires that a bill that include several topics such as law enforcement, ID requirements, employment verification, access to public benefits, etc. Table 1 highlights the different thematic areas covered by each state's respective omnibus immigration bill.

Table 1: Omnibus Reform Legislation

\begin{tabular}{|c|c|c|c|c|c|c|c|}
\hline State & $\begin{array}{c}\text { Law } \\
\text { Enforce }\end{array}$ & IDs & Employ & Edu & $\begin{array}{l}\text { Public } \\
\text { Benefits }\end{array}$ & $\begin{array}{c}\text { Harbor } \\
\text { /Transport } \\
\text { /Rental }\end{array}$ & Other \\
\hline Alabama & $\mathrm{X}$ & $\mathrm{X}$ & $\mathrm{X}$ & $\mathrm{X}$ & $\mathrm{X}$ & $\mathrm{X}$ & $\mathrm{X}$ \\
\hline Arizona & $\mathrm{X}$ & $\mathrm{X}$ & $\mathrm{X}$ & & & $\mathrm{X}$ & \\
\hline Florida & $\mathrm{X}$ & & $\mathrm{X}$ & & & & $\mathrm{X}$ \\
\hline Georgia & $\mathrm{X}$ & & X & & $\mathrm{X}$ & $\mathrm{X}$ & \\
\hline Indiana & $\mathrm{X}$ & $\mathrm{X}$ & $\mathrm{X}$ & & $\mathrm{X}$ & $\mathrm{X}$ & $\mathrm{X}$ \\
\hline Kentucky & $\mathrm{X}$ & & & & & $\mathrm{X}$ & \\
\hline Maryland & $\mathrm{X}$ & & & & & & \\
\hline Mississippi & $\mathrm{X}$ & $\mathrm{X}$ & $\mathrm{X}$ & $\mathrm{X}$ & $\mathrm{X}$ & & $\mathrm{X}$ \\
\hline Oklahoma & $\mathrm{X}$ & $\mathrm{X}$ & $\mathrm{X}$ & & & & \\
\hline South & & & & & & & \\
\hline Carolina & $\mathrm{X}$ & $X$ & $X$ & & $X$ & $X$ & \\
\hline Utah & $\mathrm{X}$ & & & & $\mathrm{X}$ & & $\mathrm{X}$ \\
\hline
\end{tabular}

The apogee for the discussion and debate of this immigration reform legislation was in late 2010 and 2011. It is noteworthy that only one bill was introduced during 2012 (in Mississippi in February), and while it was approved in the House, it ended up dying in committee in the Mississippi Senate. 


\section{Immigration Policy and Partisan Politics in the State Legislatures}

While this omnibus legislation varied across the states, one common thread that united it was its focus on law enforcement, in particular the purpose, explicit or implicit, of creating conditions under which undocumented immigrants would feel pressure to leave the state. Along this same line of making life sufficiently difficult and unpleasant that undocumented immigrants in the state would leave and those outside the state would not migrate to the state, depending on the state the legislation also included new personal identification requirements, made the employment of undocumented immigrants more difficult, made travel and apartment rentals more onerous and complex, and restricted access by undocumented immigrants to public benefits. While many, though not all, of these provisions were at least temporarily blocked by the federal courts, the legislation often was successful in its primordial goal of signaling to undocumented immigrants that they were unwelcome in the state which in turn caused many to leave and others to choose to not migrate in the first place. A detailed review of the legislation summarized in Table 1 is located in Appendix 1.

\section{Statistical Analysis}

\section{Analysis Population}

The analysis population for the second-stage of this study consists of the final-passage vote, or its closest approximation, which took place in a legislative chamber or committee on legislation classified by the NCSL as omnibus immigration legislation. A host of other votes in many of the legislative bodies which took place during the debate over the omnibus legislation were also examined, with results which do not differ substantively in most instances from the specific vote examined here for each legislative body. In all, a total of 18 votes from 18 legislative bodies (eight houses, eight senates, two house committees) which took place between 2010 and 2012 were examined, representing the totality of bodies where a recorded vote was held on restrictive omnibus immigration reform legislation in the U.S. state legislatures during this time frame. 


\section{Immigration Policy and Partisan Politics in the State Legislatures}

\section{Partisanship and Support for/Opposition to the Omnibus Legislation}

Table 2 provides a summary of the vote results in these 18 legislative bodies, indicating the proportion of the members of the Republican and Democratic delegations (and in three instances the single independent casting a vote) who cast a vote in favor of or opposed to restrictive omnibus reform legislation, along with those who were present for the vote but abstained. Two principal conclusions can be drawn from Table 2 .

First, the legislation was almost universally opposed by Republican legislators, with a mean of $96 \%$ voting in favor, $2 \%$ against, and $2 \%$ abstaining. In seven of the 18 bodies, every single Republican voted for the legislation, while only in two bodies (Arizona Senate, Indiana Senate) did the proportion in favor drop below $90 \%$, and in one of these cases, the Arizona Senate, the sole two dissenters did not vote against the bill but rather abstained.

Second, while an overwhelming majority of Democrats opposed the legislation, a not insignificant number broke with the majority of the party to cast a vote in favor of the restrictive omnibus legislation along with their GOP colleagues. On average, $20 \%$ of Democrats voted for the legislation across the 18 bodies, ranging from a low of $0 \%$ in the Arizona House to a high of $70 \%$ in the Oklahoma House (the only body where an absolute majority of Democrats supported the restrictive omnibus legislation).

\section{Intra-Party Dynamics and Support for/Opposition to the Omnibus Legislation}

As Table 2 makes clear, there exists scant intra-party variance among the Republican legislators in terms of their support for the restrictive omnibus immigration reform legislation. In contrast, the table reveals a notable level of variance among the Democratic Party legislators. In this section we therefore we examine differences in legislator support within the Democratic Party in regard to two crucial dimensions: Race/Ethnicity and Geography.

Table 3 provides the racial/ethnic distribution of the legislators who cast a vote on the omnibus legislation. While the Republican Party in these bodies is almost monolithically 


\section{Immigration Policy and Partisan Politics in the State Legislatures}

Anglo, the Democratic Party is noticeably more diverse. In these 18 legislative bodies, an average of $98 \%$ of the Republican legislators are Anglo, with a median of $100 \%$. In contrast, an average of $57 \%$ of the Democratic legislators are Anglos, followed in prominence by African Americans with a mean of $31 \%$ and Hispanics with a mean of $8 \%$.

In order to better understand the combined impact of Race/Ethnicity and Geography on the support by Democratic legislators for the omnibus immigration reform legislation, analysis was conducted to determine the relationship between those factors and a favorable vote by the Democratic legislators. The dependent variable was coded 1 (in favor) if either the Democrat voted for the bill or else abstained while a majority of his/her copartisans voted against it. ${ }^{4}$

In the analysis, separate dummy variables were created for Anglos from Urban areas, Anglos from Rural areas, African Americans from Urban areas, and African Americans from Rural areas. The small number of cases of Hispanic, Asian American and Native American legislators prevented splitting them into separate urban and rural groupings. Furthermore, in the analysis the Democratic Asian American legislators (three total) and Native American legislators (13 total) are grouped into an "Others" category. The geographic location of the legislator's district was coded employing the six-point classification scheme of the U.S. Department of Health and Human Services. ${ }^{5}$ All instances where the lead county in a legislator's electoral district had a population of 250,000 or greater are considered as urban, while those with a population less than 250,000 are considered rural. Modifying this definition by lowering the threshold to qualify as urban to 50,000 does not affect the substantive findings of the analysis.

Given the distinct content of and dynamics surrounding the legislation being voted on in the states, a binary "fixed effects" variable for each state is included in the econometric

\footnotetext{
${ }^{4}$ Jones, Mark P., and Wonjae Hwang. 2005. "Party Government in Presidential Democracies: Extending Cartel Theory Beyond the U.S. Congress," American Journal of Political Science, 49: 267-83. Simply deleting the small number of abstentions instead of coding them as yea votes does not affect the substantive findings.

${ }^{5}$ Ingram, Deborah D., and Shelia J. Franco. 2012. NCHS Urban-Rural Classification Scheme for Counties. Washington D.C.: U.S. Department of Health and Human Services.
} 


\section{Immigration Policy and Partisan Politics in the State Legislatures}

analysis, albeit not shown in Table 4 for reasons of space. The binary logit analysis and post-estimation analysis displayed in Table 4 reveals several important findings. First and foremost, there exist significant and substantive differences in Democratic legislator support for the omnibus legislation depending on the ethnic/racial-urban/rural status of an individual legislator. The legislators most likely to vote in favor of the bills were Rural Anglos, with an expected value of 0.418. After the Rural Anglos, the Urban Anglos were the most likely to cast a Yea vote, with an expected value of 0.235 . Each of these values is significantly higher than those for the African American legislators, both Urban (0.038) and Rural (0.064).

Second, the $90 \%$ confidence intervals in Table 4 indicate that the Rural Anglos were significantly more likely to vote in favor of the legislation than their fellow Anglos in urban areas, with the two groups respective confidence intervals not overlapping. Similarly, both Rural and Urban Anglos were significantly more likely to favor the bills than both Rural and Urban African Americans, with a wide gap between the lower and upper bounds of their respective $90 \%$ confidence intervals. In contrast, there does not appear to exist any noteworthy difference among African Americans based on the geographic location of their district (i.e., urban vs. rural). The number of Hispanic and Other Democratic legislators is sufficiently small as to inhibit any reliable conclusions based on the analysis, although the data at hand suggest Hispanic legislators are less likely to vote in favor of the legislation than Anglo legislators and more likely to support it than African American legislators.

The limited variance in both the vote outcome and ethnic/racial diversity within the Republican Party prevents a comparable analysis. However, a partial analysis did reveal that the small number of Hispanic Republican legislators were significantly less likely than their Anglo colleagues to support omnibus immigration reform, with expected values for Urban and Rural Anglo support of 0.977 and 0.971 respectively compared to 0.650 for Hispanics. Furthermore, while the Hispanic legislators' $90 \%$ confidence interval is unsurprisingly large given the very limited number of Hispanic GOP 


\section{Immigration Policy and Partisan Politics in the State Legislatures}

legislators, it nonetheless does not overlap with that for either the Urban Anglo or Rural Anglo Republican legislators.

\section{Public Policy Implications}

The most profound public policy impact of the state-level immigration reform legislation was not to alter the policy environment in the specific states (though this did occur to a certain extent). Rather, the legislation served to focus national attention on the topic of immigration reform and put in stark relief the distinct positions of the Republican and Democratic Parties (at least as represented by their legislative delegations in these states) on the conservative policy option of addressing undocumented immigration through a primarily punitive "attrition through enforcement" policy approach. The reform thus clarified the Democratic and Republican positions on immigration reform for voters, particularly Hispanic voters, who in 2012 overwhelming voted Democratic in the presidential (75\%) and congressional (77\%) elections. ${ }^{6}$ This signal was read loud and clear by Republicans, and is largely responsible for their current willingness to sit down with their Democratic colleagues in Washington D.C. and together craft a comprehensive immigration reform bill. Nevertheless, the unanimous Republican support for restrictive immigration reform legislation across these legislative bodies stretching from Utah to South Carolina underscores the challenges confronting Republicans such as Senators John McCain and Marco Rubio who are charged with the difficult task of brokering a deal which meets at least the minimum demands of Democrats without alienating such a large number of Republicans that the reform is rendered unviable.

From a pure public policy perspective, the debate and controversy surrounding the restrictive immigration reform legislation in the state legislatures, combined with the subsequent injunctions issued by federal courts blocking much of the actual implementation of the ensuing laws, highlighted the reality that immigration reform is not an area of public policy that can be addressed by the individual states. Rather, only the federal government is endowed with the necessary constitutional power, nation-wide

\footnotetext{
${ }^{6}$ Latino Decisions 2012 Election Eve Poll. http://www.latinodecisions.com/2012-election-eve-polls/.
} 


\section{Immigration Policy and Partisan Politics in the State Legislatures}

vision, and financial and logistical resources to develop and implement a broad and strategic immigration reform designed to fix the country's currently broken immigration system.

\section{Conclusion}

The debate over restrictive omnibus immigration reform legislation at the state-level between 2010 and 2012 helped convert immigration reform into a highly salient issue in the 2012 campaign, particularly for Hispanic voters. It also unfairly or fairly, crystallized an image, especially among many Hispanics, of the Republican Party as being on the side of anti-immigrant/anti-Hispanic forces and, to a lesser extent, of the Democratic Party being an advocate for the interests of immigrants/Hispanics.

This image proved to be disastrous for the GOP in the 2012 election as the party saw its support drop among Hispanics. Mitt Romney garnered only 23\% (Latino Decisions) or 27\% (National Exit Poll) of the Hispanic vote and less than a quarter in the key battleground states of Colorado (where only $10 \%$ of Hispanic voters cast a ballot for Romney) and Nevada (20\%) while at the same time performing sufficiently poorly in the red states of Arizona (20\%) and Texas (29\%) that doubts began to be raised about how "solid Republican" these states might be in the future. ${ }^{7}$ Cognizant that the Republican Party does not have a future as a viable national party if its share of the Hispanic vote continues to shrink, while the number of Hispanic voters continues its inexorable rise, GOP leaders in Congress are now seriously working on immigration reform legislation. This transformation in the GOP attitudes towards immigration reform, in turn, can in many ways trace some of its origins to SB-1070, legislation that helped set in motion the nation-wide forces that created the incentives for Republican lawmakers to support comprehensive immigration reform at the federal level.

\footnotetext{
${ }^{7}$ Latino Decisions 2012 Election Eve Poll. http://www.latinodecisions.com/2012-election-eve-polls/.
} 
Immigration Policy and Partisan Politics in the State Legislatures

\section{APPENDIX 1: SYNOPSES OF THE OMNIBUS LEGISLATION BY STATE ${ }^{8}$}

\section{Alabama HB56}

Introduced on March 1, 2011 and passed in both chambers by large margins in three months (H: 73-28, S: 26-6).

Law enforcement: Law enforcement is required to determine the immigration status of a person if he/she is involved in the enforcement of any other law where reasonable suspicion exists that the person is an undocumented immigrant. However, race, color or national origin cannot be used during implementation. The possession of certain IDs presumes lawful presence. Additionally, citizens and legal residents can sue the state or localities that restrict the enforcement of federal law (e.g., 'sanctuary cities').

IDs: Willful failure to complete or carry an alien registration document is a crime.

Employment: It is unlawful for undocumented immigrants to apply, solicit or perform work. All public employers are required to use E-Verify, and public contractors may not employ undocumented immigrants.

Education: Public K-12 schools are required to determine every student's immigration status and submit annual reports to the state. Undocumented immigrants are banned from attending college or receiving any state scholarships, grants or financial aid.

Public benefits: Undocumented immigrants are prohibited from receiving any state or local public benefits.

Harbor/Transport/Rental: It is unlawful for a person to transport, conceal, harbor, shield or enter into a rental agreement with an undocumented immigrant.

\footnotetext{
${ }^{8}$ This appendix draws very heavily on the summaries of the legislation provided by the NCSL: http://www.ncsl.org/issues-research/immig/omnibus-immigration-legislation.aspx. Non-NCSL sources are provided at the end of each synopsis.
} 


\section{Immigration Policy and Partisan Politics in the State Legislatures}

Voting: Proof of citizenship and residency is required before voting.

\begin{tabular}{|c|c|c|c|c|c|c|c|}
\hline & $\begin{array}{c}\text { Law } \\
\text { Enforcement }\end{array}$ & IDs & Employ & Edu & $\begin{array}{c}\text { Public } \\
\text { Benefits }\end{array}$ & $\begin{array}{c}\text { Harbor } \\
\text { Transport } \\
\text { /Rental }\end{array}$ & Other \\
\hline Alabama & $\mathrm{X}$ & $\mathrm{X}$ & $\mathrm{X}$ & $\mathrm{X}$ & $\mathrm{X}$ & $\mathrm{X}$ & $\mathrm{X}$ \\
\hline
\end{tabular}

\section{Arizona SB1070 and HB2162}

Introduced January 13, 2010 and passed both chambers (H: 33-22, S: 16-11) on April 29, 2010.

Law Enforcement: Law enforcement is prohibited from restricting the enforcement of federal immigration laws. Law enforcement must reasonably attempt to determine the immigration status of a person involved in a lawful stop, detention or arrest in the enforcement of any other law where reasonable suspicion exists that the person is an undocumented immigrant. However race, color or national origin cannot be considered during implementation. Possession of certain IDs presumes lawful presence. Additionally, residents may sue the state or localities that restrict the enforcement of federal law.

IDs: There are penalties for willful failure to complete or carry an alien registration document.

Employment: It is unlawful for an occupant of a motor vehicle to hire workers on a street, roadway, or highway if the vehicle blocks or impedes normal traffic. It also is unlawful for an unauthorized immigrant to knowingly apply, solicit or perform work.

Harbor/Transport/Rental: It is unlawful to transport, conceal, harbor, shield, or encourage an alien to come to Arizona. 


\section{Immigration Policy and Partisan Politics in the State Legislatures}

\begin{tabular}{|c|c|c|c|c|c|c|c|}
\hline & $\begin{array}{c}\text { Law } \\
\text { Enforcement }\end{array}$ & IDs & Employ & Edu & $\begin{array}{c}\text { Harbor } \\
\text { Benefits }\end{array}$ & $\begin{array}{c}\text { /Transport } \\
\text { /Rental }\end{array}$ & Other \\
\hline Arizona & $\mathrm{X}$ & $\mathrm{X}$ & $\mathrm{X}$ & & & $\mathrm{X}$ & \\
\hline
\end{tabular}

\section{Florida HB7089}

Introduced on March 10, 2011 and died at the end of session on May 7, 2011 when the Republican Speaker of the House did not schedule the bill for floor action after it had passed out of committee.

Law Enforcement: The state and political subdivisions are prohibited from limiting or restricting the enforcement of federal immigration laws. The state or its political subdivisions may not be prohibited from maintaining or exchanging information regarding immigration status. Law enforcement may determine the immigration status of a person subject to criminal investigation if reasonable suspicion exists that the person is undocumented. If arrested, a reasonable attempt shall be made to determine the person's immigration status. Race, color or national origin may not be considered in enforcement.

Employment: Employers are required to use E-Verify. They may not knowingly employ undocumented immigrants. Public employers are prohibited from contracting for services with contractors not using E-Verify.

Crime: Enhanced maximum criminal penalties may be levied when offenses are committed by undocumented immigrants.

\section{Why It Failed:}

- Democrats opposed the legislation.

- Republicans were divided, many because of opposition to the legislation by the Florida Chamber of Commerce, the Associated Industries of Florida, the agriculture industry and immigrants. 


\section{Immigration Policy and Partisan Politics in the State Legislatures}

- Senate Judiciary Chair Anitere Flores had already stripped out E-Verify from the stronger House version that passed the House and publically opposed an Arizonastyle immigration legislation.

- There were protests by students and immigrant groups.

- Gov. Rick Scott did not endorse the bills, though he supports immigration reform.

\section{Sources}

- http://www.sunshinestatenews.com/story/e-verify-bill-dying-slow-death-senate

- http://articles.cnn.com/2011-04-26/us/florida.immigration.bill_1_immigrationlaw-immigration-reform-senate-bill?_s=PM:US

\begin{tabular}{|c|c|c|c|c|c|c|c|}
\hline & $\begin{array}{c}\text { Law } \\
\text { Enforcement }\end{array}$ & IDs & Employ & Edu & $\begin{array}{c}\text { Public } \\
\text { Benefits }\end{array}$ & $\begin{array}{c}\text { Harbor } \\
/ \text { Transport } \\
/ \text { Rental }\end{array}$ & Other \\
\hline Florida & $\mathrm{X}$ & & $\mathrm{X}$ & & & & $\mathrm{X}$ \\
\hline
\end{tabular}

\section{Georgia HB87}

Introduced in late January, HB87 was signed five months later on May 13, 2011. It passed both chambers by large margins (H: 112-59, S: 37-19)

Law Enforcement: Law enforcement is authorized to verify a suspect's immigration status if the suspect cannot provide identification and probable cause exists to believe the suspect is guilty. Race, color or national origin may not be considered in implementing the law.

Employment: All contractors must include in their bids for publicly funded projects an affidavit attesting that the contractor and any subcontractor uses E-Verify. The state will conduct compliance audits on public employers with penalties for non-compliance. Employers cannot claim deductible business expenses for wages paid to an employee in excess of $\$ 600$ unless the employee has been approved to work in the U.S. using EVerify. 


\section{Immigration Policy and Partisan Politics in the State Legislatures}

Public Benefits: Applicants shall provide at least one secure and verifiable document in addition to an affidavit of lawful presence (for those 18 and over only).

Harbor/Transport/Rental: Persons transporting an undocumented immigrant while committing another crime may be charged with a misdemeanor. The same penalties exist for a person convicted of knowingly concealing, harboring, or shielding an illegal alien from detection; and for a person inducing an illegal alien to enter the state.

\begin{tabular}{|l|c|c|c|c|c|c|c|}
\hline & $\begin{array}{c}\text { Law } \\
\text { Enforcement }\end{array}$ & IDs & Employ & Edu & $\begin{array}{c}\text { Public } \\
\text { Benefits }\end{array}$ & $\begin{array}{c}\text { Harbor } \\
\text { Transport } \\
\text { /Rental }\end{array}$ & Other \\
\hline Georgia & $\mathrm{X}$ & & $\mathrm{X}$ & & $\mathrm{X}$ & $\mathrm{X}$ & \\
\hline
\end{tabular}

\section{Indiana SB590}

Introduced in January 2011 and signed on May 10, 2011. It passed both chambers by large margins (H: 68-31, S: 35-15).

Law Enforcement: Law enforcement may arrest suspects if there is a removal order, detainer, notice of action or if there is probable cause to believe the person has been indicted or convicted of one or more aggravated felonies.

Harbor/Transport/Rental: Law enforcement can impound motor vehicles for moving, transporting, concealing, harboring or shielding undocumented immigrants. The state must then verify the citizenship or immigration status of criminal offenders. Status as a foreign national must be considered in setting bail or bond requirements.

IDs: The law criminalizes fake IDs and identity fraud.

Employment: State agencies, political subdivisions and contractors with public contracts are required to use E-Verify. Certain state income tax credits and deductions are banned 


\section{Immigration Policy and Partisan Politics in the State Legislatures}

for individuals who are prohibited from being hired as employees, unless the employer participates in E-Verify.

Public Benefits. State agencies and localities must verify each individual's eligibility for public benefits and unemployment compensation.

Studies/Reimbursement of costs. The Office of Management and Budget must calculate the costs of undocumented immigrants to Indiana and request Congressional reimbursement. The State urges the Legislative Council to assign immigration topics for further study and consult with the Lieutenant Governor.

\begin{tabular}{|c|c|c|c|c|c|c|c|}
\hline & $\begin{array}{c}\text { Law } \\
\text { Enforcement }\end{array}$ & IDs & Employ & Edu & $\begin{array}{c}\text { Public } \\
\text { Benefits }\end{array}$ & $\begin{array}{c}\text { Harbor } \\
\text { Transport } \\
/ \text { Rental }\end{array}$ & Other \\
\hline Indiana & $\mathrm{X}$ & $\mathrm{X}$ & $\mathrm{X}$ & & $\mathrm{X}$ & $\mathrm{X}$ & $\mathrm{X}$ \\
\hline
\end{tabular}

\section{Kentucky SB6}

Introduced January 4, 2011 and passed the Senate by a 24-14 vote. The bill died after never receiving a hearing in the House Local Government Committee.

Law Enforcement: Law enforcement may determine the immigration status of a person on reasonable suspicion, make arrests of undocumented immigrants upon probable cause, and transfer convicted undocumented immigrants to ICE custody. Officers are indemnified if sued. The state and sub-entities are barred from adopting policies, administrative regulations, or laws that restrict the enforcement of federal immigration law. Furthermore, officials or agencies may not be prohibited from sharing the immigration status of a person under specific instances.

Harbor/Transport/Rental: It is unlawful for a person to transport, conceal, or encourage undocumented immigrants to come to Kentucky. 


\section{Immigration Policy and Partisan Politics in the State Legislatures}

\section{Why It Failed:}

- The immigration bill would cost the state $\$ 40$ million a year.

- Large protests by immigrant communities.

- Sixty leading business executives signed a letter laying out the negative economic consequences of the anti-immigration campaign, such as canceled contracts, boycotts and a decline in tourism.

- The Kentucky Association of Chiefs of Police, the Kentucky Sheriff's Association and the Kentucky Magistrates and Commissioners Association all raised questions about the ultimate cost of the bill in terms of additional training, police manpower and the operations of already-strapped county jails.

- The House was controlled by Democrats and there was a Democratic governor.

\section{Sources}

- http:/www.kentucky.com/2011/01/14/1597995/immigration-bill-would-coststate.html

- http://www.whas11.com/community/Protesters-rally-against-immigration-bill-atKy-Capitol-.html

- $\quad$ http://www.mcclatchydc.com/2011/03/29/111220/commentary-the-death-ofkentuckys.html

- http://www.courierpress.com/news/2011/feb/12/immigration/

\begin{tabular}{|c|c|c|c|c|c|c|c|}
\hline & $\begin{array}{c}\text { Law } \\
\text { Enforcement }\end{array}$ & IDs & Employ & Edu & Benefits & $\begin{array}{c}\text { Harbor } \\
\text { /Transport } \\
\text { /Rental }\end{array}$ & Other \\
\hline Kentucky & $\mathrm{X}$ & & & & & $\mathrm{X}$ & \\
\hline
\end{tabular}

\section{Maryland HB744}

Introduced February 10, 2011 and voted down by the House Judiciary Committee 11-7.

Law Enforcement: Law enforcement is authorized to verify the immigration status of specified persons. Officers who encounter and detain in the normal course of their duties 


\section{Immigration Policy and Partisan Politics in the State Legislatures}

an individual who law enforcement determines is an undocumented immigrant are required to inform the federal government as soon as possible. However, race, color or national origin cannot be used during implementation.

\section{Why it Failed:}

- Democrats control every branch of government in Maryland and actively opposed the legislation.

\begin{tabular}{|c|c|c|c|c|c|c|c|}
\hline & $\begin{array}{c}\text { Law } \\
\text { Enforcement }\end{array}$ & IDs & Employ & Edu & Benefits & $\begin{array}{c}\text { Harbor } \\
\text { /Transport } \\
/ \text { Rental }\end{array}$ & Other \\
\hline Maryland & $\mathrm{X}$ & & & & & & \\
\hline
\end{tabular}

\section{Mississippi HB488}

Introduced on February 13, 2012 and passed the House with a 70-48 vote. The bill was never brought up for debate in the Senate.

Law Enforcement: No person or office shall limit the enforcement of federal immigration laws. For any lawful stop, detention, or arrest in the enforcement of other laws, where reasonable suspicion exists that the person is undocumented, a reasonable attempt shall be made to determine the immigration status of the person. The possession of certain IDs presumes lawful presence. Law enforcement is indemnified for the implementation of this bill. There is a prohibition of restricting the sending, receiving or maintaining information relating to the immigration status with any other entity. Residents may sue the state or any subdivision for restricting the enforcement of federal immigration laws.

IDs: Willful failure to complete or carry an alien registration document is a crime.

Education: Requires public (K-12) schools to determine the immigration status of students. 


\section{Immigration Policy and Partisan Politics in the State Legislatures}

Public Benefits: Prohibits undocumented immigrants from entering into business transactions with the state.

Employment: Employers are prohibited from hiring undocumented immigrants. All employers must use E-verify and keep records of employment verification for the duration of the employee's employment or 3 years whichever is longer.

Immigration Reimbursement Fund: The state will reimburse localities for funds spent on local jails for the incarceration of certain undocumented immigrants.

\section{Why It Failed:}

- The Democrat who chaired the Senate Judiciary Committee refused to bring the bill up for consideration by the committee.

- The Mississippi Sheriffs' Association, Chiefs of Police, Municipal League and Association of Supervisors all urged lawmakers to oppose HB 488, calling it an "unfunded mandate" and highlighted problems enforcing the law as well as the cost to taxpayers.

- Mississippi farming groups also came out against HB 488, asking lawmakers to consider the impact of neighboring Alabama's immigration law. Since Alabama passed their immigration law (HB 56), the state has been subject to costly federal lawsuits, rotting crops, lost income and sales tax revenue, federal lawsuits and damage to local businesses

- Strong support in the African American and Latino communities to kill the bill.

\section{Sources}

- http://immigrationimpact.com/2012/04/03/mississippi-lawmakers-kill-statesextreme-immigration-bill-although-immigration-provisions-may-loom/

- $\quad$ http://www.thenation.com/article/167465/how-mississippis-blackbrown-strategybeat-souths-anti-immigrant-wave\# 


\section{Immigration Policy and Partisan Politics in the State Legislatures}

\begin{tabular}{|c|c|c|c|c|c|c|c|}
\hline & $\begin{array}{c}\text { Law } \\
\text { Enforcement }\end{array}$ & $\mathrm{IDs}$ & Employ & Edu & $\begin{array}{c}\text { Public } \\
\text { Benefits }\end{array}$ & $\begin{array}{c}\text { Harbor } \\
\text { Transport } \\
/ \text { Rental }\end{array}$ & Other \\
\hline Mississippi & $\mathrm{X}$ & $\mathrm{X}$ & $\mathrm{X}$ & $\mathrm{X}$ & $\mathrm{X}$ & & $\mathrm{X}$ \\
\hline
\end{tabular}

\section{Oklahoma SB908 and HB1446}

Both bills were introduced on February 7, 2011. The House passed its version by a wide margin 85-7 and the Senate passed its version with a 29-15 vote. The Senate then passed an amended version of the House bill by a wide margin 37-8. However, the bill died when a revised bill failed to emerge from the conference committee.

Law enforcement: Law enforcement is required to determine the immigration status of a person involved in the enforcement of any other law where reasonable suspicion exists that the person is an undocumented immigrant. However, race, color, or national origin cannot be used during implementation. The possession of certain IDs presumes lawful presence. Citizens and legal residents can sue the state or localities that restrict enforcement of federal law.

IDs: Willful failure to complete or carry an alien registration document is a crime.

Employment: It is unlawful for undocumented immigrants to apply, solicit or perform work. All public employers required to use E-Verify, and specifically, public contractors may not employ undocumented immigrants.

\section{Why It Failed:}

- Republicans complained that the bill didn't target employers who hire undocumented workers and Democrats were of the position that immigration is a policy area that should be addressed only by the federal government.

- Legislators on both sides of the partisan aisle expressed concerns about its high implementation costs. 


\section{Immigration Policy and Partisan Politics in the State Legislatures}

- Business and faith leaders also spoke out forcefully against the bill, citing the likelihood it would harm the state's already-struggling economy.

\section{Sources}

- http://immigrationimpact.com/2011/05/20/more-states-toss-costly-immigrationlegislation-in-final-days-of-session-2/

- http://www.progressivestates.org/news/dispatch/states-continue-reject-broad-anti$\underline{\text { immigrant-laws-concern-about-economic-effects-grows }}$

\begin{tabular}{|c|c|c|c|c|c|c|c|}
\hline & $\begin{array}{c}\text { Law } \\
\text { Enforcement }\end{array}$ & IDs & Employ & Edu & $\begin{array}{c}\text { Public } \\
\text { Benefits }\end{array}$ & $\begin{array}{c}\text { Harbor } \\
\text { Transport } \\
/ \text { Rental }\end{array}$ & Other \\
\hline Oklahoma & $\mathrm{X}$ & $\mathrm{X}$ & $\mathrm{X}$ & & & & \\
\hline
\end{tabular}

\section{South Carolina SB20}

Introduced January 11, 2011, the bill was signed by the governor on June 27, 2011.

Law enforcement: If there is reasonable suspicion that a person who is stopped, detained, or arrested is an unlawfully in the United States, law enforcement is required to verify the person's immigration status. However, race, color or national origin may not be considered during implementation.

Employment: It is unlawful for undocumented immigrants to knowingly apply, solicit or perform work. Public contractors may not knowingly employ undocumented immigrants, and they in addition to subcontractors are required to use E-Verify. After being hired, an employer has three days to check an employee's verification in E-verify.

Harbor/Transport/Rental: It is unlawful to transport, conceal, harbor, shield or enter into a rental agreement with an undocumented immigrant. 


\section{Immigration Policy and Partisan Politics in the State Legislatures}

Public Benefits: Undocumented immigrants are prohibited from receiving any public benefits except certain emergency exemptions.

IDs: It is unlawful for a person to make, issue, or sell, a fake ID. It is also unlawful for a person (18 or older) not to carry any certificate of alien registration.

\begin{tabular}{|c|c|c|c|c|c|c|c|}
\hline & $\begin{array}{c}\text { Law } \\
\text { Enforcement }\end{array}$ & IDs & Employ & Edu & $\begin{array}{c}\text { Public } \\
\text { Benefits }\end{array}$ & $\begin{array}{c}\text { Harbor } \\
\text { /Transport } \\
\text { /Rental }\end{array}$ & Other \\
\hline $\begin{array}{c}\text { South } \\
\text { Carolina }\end{array}$ & $\mathrm{X}$ & $\mathrm{X}$ & $\mathrm{X}$ & & $\mathrm{X}$ & $\mathrm{X}$ & \\
\hline
\end{tabular}

\section{Utah H116, HB466, HB469, HB497}

All four bills were introduced between early February and March of 2011. By March 8, 2011, all four bills had passed both chambers: HB116 (H: 41-32, S: 19-5); HB466 (H: 72-0, S: 25-1); HB469 (H: 53-18, S: 19-6); HB497 (H: 59-15, S: 22-5).

\section{H116}

Temporary Guest Worker Program: The law establishes a temporary guest worker program where certain eligibility requirements apply. Each application requires a $\$ 1000$ fine if the individual entered the country legally or \$2500 if entered illegally. Participants must make good faith efforts to become English-proficient. Private employers are prohibited from knowingly hiring an undocumented individual without a permit, and those with more than 15 employees must verify eligibility through E-Verify, an equivalent federal system, the Social Security Administration, or an equally reliable independent third-party system. 


\section{Immigration Policy and Partisan Politics in the State Legislatures}

Law Enforcement: Law enforcement shall request an individual's immigration status for Class A misdemeanors or felonies and may request verification for Class B or C misdemeanor offenders.

\section{H466}

State Commission on Immigration: The law creates an advisory Utah Commission on Immigration and Migration composed of 27 members of the legislature, executive agencies, and the public. They shall review the impact of undocumented immigration and immigration laws, develop a state plan on immigration and integration and make recommendations to the governor and the legislature.

Migrant Worker Visa Pilot Project: The law establishes a migrant worker visa pilot project and authorizes Utah to work with the Mexican state of Nuevo León to fill jobs in Utah.

H469

Sponsor Resident Immigrant Pilot Program: A U.S. citizen and Utah resident may sponsor a foreign national as a resident immigrant whom may then seek employment.

H497 (the bill examined in the roll call vote analysis)

Law Enforcement: The law requires officers to verify the immigration status of a person arrested for a felony or a Class A misdemeanor and a person booked for Class B or C misdemeanors.

Public Benefits: The law requires verification of immigration status regarding application for public services or benefits, except as exempted by federal law. 
Immigration Policy and Partisan Politics in the State Legislatures

\begin{tabular}{|c|c|c|c|c|c|c|c|}
\hline & $\begin{array}{c}\text { Law } \\
\text { Enforcement }\end{array}$ & IDs & Employ & Edu & $\begin{array}{c}\text { Public } \\
\text { Benefits }\end{array}$ & $\begin{array}{c}\text { Harbor } \\
\text { /Transport } \\
\text { /Rental }\end{array}$ & Other \\
\hline Utah & $X$ & & & & $X$ & & $\mathrm{X}$ \\
\hline
\end{tabular}

